\title{
Heroism in three Old English poems: A Christian approach
}

\author{
Catherine Woeber \\ Department of English \\ Potchefstroom University for CHE \\ POTCHEFSTROOM
}

\begin{abstract}
It has been contended that the value system and terminology of Old English heroic poetry were not suitable vehicles for the later religious poetry, that their Germanic garb ill-fitted the Christian poems. This view, however, does not take cognisance of the the fact that there exists a Christian heroism in its own right. Only Christian scholarship can fully account for this phenomenon and show how the subject matter of this poetry is consonant with the heroic diction and formulae in which it is couched. Three Old English poems dealing with aspects of 'Christ' saving ministry will be examined to show that Christ is depicted as a hero bringing victory through suffering in God's plan of salvation, rather than as a heroic warrior as he is usually regarded, fighting in the armour of the Germanic hero. A close study of these poems shows that the authors understood Christian heroism to mean more than brave battling on the side of God; rather, it is complete submission to the will of God.
\end{abstract}

\section{Introduction: Quin Hinieldus cum Christo?}

What has Ingeld to do with Christ? It is the thought behind Alcuin's famous remonstrance to the monks of Lindisfarne that has prompted this approach to the relation between Germanic and Christian heroism. 'With

1 Alcuin of York in 797 was not the first person to be alarmed by the preference for heroic tales about heroes like Beowulf (or Ingeld, a character in the epics Beowulf and Widsith). The early Christian writer Tertullian raised the same issue by asking "What has Athens to do with Jerusalem?" and the rather crusty Jerome asked "How can Horace go with the Psalter, Virgil with the Evangelists, Cicero

Koers 60(3) 1995:359-379 
these words the Abbot scolded his monks for their preference for listening to the old heroic lays rather than Biblical stories in the refectory. Was this because the epics were so much more exciting than the Scriptures? Were the secular values of Anglo-Saxon society more inveterate than the religious ideals the monasteries sought to inculcate? There is an element of truth in both which goes some way to account for the fact that early Christian poetry relied heavily on Germanic diction and metaphor for its effectiveness. In most Christian poems there is a residual heroic quality in the vocabulary and treatment of certain themes. Genesis $B$ from the Junius MS, for example, one of the earliest poems, presents God and his angels, Satan and his devils, and God and Adam as Germanic lords and their retainers. The metaphor is extremely appropriate, for as the concept of loyalty - that of the thane to his lord - is integral to Germanic heroic poetry, so the same concept is at the core of the new ethical system by which the behaviour of Satan and Adam is judged and found wanting.

But beyond the metaphor, it was the heroic diction, the formulas and formulaic units, on which the Christian poets leaned heavily. In the earlier poetry at least, the Christian subject matter usually comprised exciting adventures and martial exploits since formulas already existed for them. Germanic words and compounds used to express the idea of 'ruler' were adapted to serve as synonyms for God, like waldend and dryhten. Yet it has been contended that the value system and terminology of heroic poetry were not suitable vehicles for the emergent religious poetry, that Germanic garb hung on the poems "like a giant's robe/Upon a dwarfish thief" (Macbeth V:II:21-22). Greenfield (1965:102) offers a summary of these views:

The Christian epic hero has been viewed as garbed in the borrowed robes, or rather armour, of his Germanic counterpart, as a warrior venturing into battle against spiritual evil and the forces of Satan even as the secular lord and his comitatus engaged the armed forces of predatory enemies. There is, of course, much truth in this picture ... Christ and his saints come marching in with many of the qualities of a Beowulf or a Byrhtnoth. And the phraseology and tone in which these qualities and actions are depicted in the poetry are similar to those arraying the heroes of the Anglo-Saxon secular world.

with the Apostles?" The original text all these writers are echoing, of course, is 2 Corinthians 6:14-15, where Paul asks "What accord has Christ with Belial?" 
Catherine Woeber

Rosemary Woolf (1968:164) has declared that heroic convention was never satisfactorily adapted to Christian themes. "The heroic formulae were ... usually merely decorative, for any more integral use of the old style would have resulted in a deep-rooted incongruity; but nevertheless, even this superficial usage is unsatisfactory ...". Shippey (1972:114) also mentions an incongruity between the "highly developed military vocabulary and resolutely abrupt syntax" of the heroic tradition, and the "alien subjects - notably the virtues of humility and passivity [which] sought expression in a native style". This commonplace of Old English criticism has been attributed by Hermann (1982:22-23) to the "literalminded readers of the twentieth-century", who are unable to conceptualise the figure of the miles Christi, rooted as they are "in a rather virulent strain of twentieth-century historicism". This article takes issue with such criticism, arguing that these views do not take cognisance of the fact that there exists a Christian heroism in its own right. Though based on values different from those of Germanic heroism, it nevertheless holds its own beside its earlier counterpart. Only a Christian critical approach can fully account for this phenomenon, and show how the subject matter of this poetry is consonant with the heroic diction in which it is couched.

\section{Difference between Germanic and Christian heroism}

What makes Christ, as depicted in this poetry, the champion of God in a way, say, that the Germanic hero never can be; and why can heroic diction be so suitably applied to him? He exhibits that quality peculiar to the Christian hero, that "better fortitude/Of patience and heroic martyrdom" (Paradise Lost IX:31-32) by which he trusts solely in God for his strength. The extent to which his own will is brought in line with that of God measures his worth as a Christian hero. And it is only through patience and endurance that this alignment occurs. The poet John Milton, writing some eight centuries after the Anglo-Saxon period, was particularly cognisant of this concept.

Patience is the virtue which shows itself when we peacefully accept God's promises, supported by confidence in the divine providence, power and goodness: also when we bear any evils that we have to bear calmly, as things which our supreme Father has sent for our good (Milton, 1973:662). 
That Germanic heroic terms are therefore applicable to the heroism of Christian saints does not, of course, erase the problem inherent in this question of fortitude. If the saint is essentially a passive hero, relying on God for his/her strength rather than trusting in his/her own, surely those terms which depict an active Germanic hero, in full armour and in search of his own dom (renown) and lof (praise), must be incongrous in a Christian context?

Beowulf, hero of the eighth-century eponymous epic, is a brave man who is committed to society: to the people of Hrothgar when, as hero, he accomplishes the death of Grendel, and to his own people as their king, by the slaying of the dragon. Yet this commitment only furthers his own distinction; in essence, the pursuit of his own lasting reputation drives him on to deeds of valour. In contrast it is service to God which sustains the Christian hero in his/her battle of suffering; God's glory is the paramount issue and this is achieved through the saint's peowdom (service) and martyrhad (martyrdom). The Germanic warrior's motivation is essentially selfish, although it benefits society; that of the saint, especially Christ himself, is selfless, a renunciation of life (cf. Luke 9:24 and John 12:25). The Germanic hero is a man of great physical prowess and courage, and uses his strength to serve the interests of his lord and kinsmen. We are told that Beowulf trusts in his own strength at a critical juncture in the accomplishment of his three heroic deeds (1270, 1533, 2540). Because his valour is his own, any reputation he gains accrues to him. The twelve warriors who encircle Beowulf's barrow at the end of the epic extol his courageous deeds in typical Germanic fashion (3169-82). In contrast, the Christian hero is not necessarily a man of physical strength; his/her holiness comes from God and so his/her life is a witness to the

2 While acknowledging the accepted Christian values of the epic Beowulf Leland Ryken shows how the depiction of the hero actually runs counter to a Christian ethic in that Beowulf, the archetypal Germanic hero, desires earthly fame, trusts in military strength, and sets great store by material wealth (Ryken, 1979:166-167). Katherine O'Brien O'Keeffi (1991:108-109) also shows how the goal of heroic conduct is marou or ealdorlangne tir, which lives on in the speech of posterity, and particularly in heroic poetry. 
Catherine Woeber

greater glory of God. ${ }^{3}$ The warrior seeks his own glory; the saint, that of God. Surely the borrowed robes of the mighty man of valour must sit awkwardly upon the ordinary person whose strength is of God?

\section{3. 'Poetic' and 'ethical' heroism}

This is not the case, however, given that there is a fundamental common ground between the two kinds of heroism, and a Christian literary appraisal of the suitability of heroic vocabulary and metaphor to Old English Christian poetry must take this into account. It is heroism which, though different in the Germanic and Christian ethical systems, is nevertheless the stuff of epic, and indeed the Bible, whose stories, as Leland Ryken (1979:22) shows "are full of the usual ingredients of literary narrative". In the Scriptural tradition we find what we might term the 'ethical' epic, the protagonist of which is Job, or the Suffering Servant (Christ) in Isaiah. Germanic or Graeco-Roman tradition, on the other hand, gives us 'poetic' epic heroes, like Beowulf or Odysseus. The two are diametrically opposed as I have shown above; yet the diction of one serves the purpose of the other because of their common ground. This will be shown through examination of the most vivid Christian poem in Old English, The Dream of the Rood. This 156-line poem relates a vision of the crucifixion given to a believer, who is then enjoined to tell of its significance to others. In so far as it portrays Christ as the active Germanic hero, and the Cross as the suffering servant - or retainer - so combining the two modes of heroism, it will serve as a useful stepping stone to the two poems I have chosen to discuss which deal exclusively with Christian heroism. Cynewulf's Christ Il, 426 lines long, recounts the Ascension and Christ's liberation of the just souls from the dead, and enjoins the reader to fix his/her hope on heaven. The anonymous Christ

3 Two hagiographical poems once ascribed to Cynewulf, Guthlac $A$ and $B$, deal with the English anchorite Guthlac who gave up a very successful martial life at the age of 24 to achieve martial prowess in a context quite opposed to that of physical warfare, namely the life of a hermit in an East-Anglian fen, and the spiritual warfare this entails. Another East Anglian, the ninth-century King Edmund, according to Aelfric's prose Lives of Saints, refused to bear arms against the Danes and resolved on a martyrdom following Christ's example. (See O'Brien O'Keeffe, 1991:115-116.) 
and Satan from the Junius MS, 729 lines in length, deals with the casting down of Satan from heaven and the temptation of Christ, and the reader is enjoined to emulate Christ in his perfect humanity.

These poems exhibit one kind of 'ethical' heroism: that of the active fighter for God, who relies on divine strength instead of his own, which sets him apart from the 'poetic' hero. So he seeks the glory of God, rather than his own tir (fame) and blced (splendour). Christ is the active warrior in his victory over the hosts of Satan in heaven (cf. Revelation 19:11-16) and his liberation of the just souls from the dead (cf. 1 Peter 3:18-20) which has become known as the Harrowing of Hell. Examples in these poems of the 'better' Christian heroism, patience as "the exercise/Of saints, the trial of their fortitude" (Samson Agonistes 1287-1288) include Christ's overcoming Satan in the Temptation in the wilderness, and his victory made once for all on the cross in the Crucifixion. The 'ethical' heroic spectrum is thus comprehensive. It embraces both the active and passive modes of fortitude; the active valour, say, of Judas Maccabeus, and the patient suffering of Job. It offers us examples of Christ's perfect fortitude completed by compassion and holiness, and the flawed fortitude of Satan, demeaned by greed and pride. Christian heroic tradition, therefore, offered the Anglo-Saxon poets a very varied palette for portraying the Christian hero.

It can be seen that the concept of heroism in Old English Christian poetry does not simply reveal a dichotomy of Germanic and Christian; the Christian itself is many-coloured and, by and large, consonant with the Germanic. But at the deepest level it is flatly contradictory. The Christian hero manifests holiness, which encourages patience, while the Germanic hero reflects courage, which leads to pride. ${ }^{4}$ Whether it is Christ hurling down Satan from heaven, or willingly going to his death on

4 The Anglo-Saxons were, of course, familiar with the Patristic doctrine that Satan had fallen through pride, and yet pride was a prominent characteristic of Germanic heroism. Another very fruitful study would be an investigation into the concept of 'mocking epic' as defined by Kratz (1980) when discussing the ninth-century Latin Waltharius, whose poet belittles the values of the Germanic heroic code as founded on the sin of avarice. To what extent were Anglo-Saxon poets mocking outmoded Germanic heroic values in their depiction of Satan as manifesting the Germanic qualities of pride and vainglory? 
the cross, what characterises the Christian hero is sanctity, that quality which comes of aligning the human will with the divine, achieved through grace alone. It must, of course, entail courage as well, but a fortitude dependent on God. "The confidence of a Christian lies not at all in himself but in his knowledge that the God to whom he has committed himself, who is both infinite and personal, is fully able to keep him in all circumstances, however weak and uncertain he knows himself to be" (Ruth Etchells, 1972:66). And in his discussion of Milton's poems, Steadman (1969:37) argues that:

The resolution of the paradox of strength in weakness lies in the distinction between acquired and infused virtues, and the decisive role of divine grace. The martyr's frailty is buttressed by divine power; his weakness is sustained by a strength infused from God. All that is demanded of him is the acknowledgement of his frailty, and a complete trust in providence. Like the fortitude of active valour the better fortitude of patience hinges upon and exemplary faith. A heroism of trust underlies action and suffering alike, and both formulae are in reality the dual modes of a heroic piety.

To keep the discussion of Christian heroism within manageable confines, I have chosen to concentrate on the figure of Christ as he is depicted in the three poems mentioned earlier. Bearing in mind Calder's observation that "Explicitly theological literature usually exhibits a profound conventionality in theme, but an analysis of an individual poem's unique structures must also be part of any valid criticism" (1981:44), I hope to show how the poets' distinctive modes of thought underscore the truism that there is more than one way to express a Christian theme.

\section{The Dream of the Rood}

One of the finest religious poems in English, The Dream of the Rood, from the Vercelli Book, reveals an almost perfect coalescence of the heroic and Christian traditions. By using the formulaic techniques of Germanic heroic poetry to present Christ as the active warrior, as well as the Christian ideal of the suffering servant in the portrayal of the Cross, the unknown poet has composed a poem which reveals the true significance of the Crucifixion. It is the very suffering and defeat in the Crucifixion which is the occasion for Christ's victory over death. Most critics tend to see Christ as the Germanic lord and the Cross as his retainer who, in an ironic reversal of his role, is compelled to acquiesce in the death of his 
Heroism in three Old English poems: A Christian approach

lord, and even be his bane. ${ }^{5}$ Certainly this depiction contributes to the richness of the poet's creation; but the poet draws on another tradition as well. By identifying the Cross with Christ's human and vulnerable nature, he fuses Germanic and Christian elements in the figure of the Cross. Likewise, although Christ is portrayed as the Germanic hero, this idea is not strictly the poet's own, as Ravennate iconography and Latin hymns of the same period - the eighth century - present him as the conquering hero (see Woolf, 1958:144-145). So also in the person of Christ the heroic and religious coalesce. In fact, the strand of heroism is ubiquitous in the fabric of the whole. The dreamer is called hoeles (hero) in lines 78 and 95, and the same word describes Christ in line 39. According to Kathleen Dubs (1975:615) the "dreamer has become hoeleo through his vision, a conversion, perhaps, but an awareness of the salutory power of the rood. And, by extension, he is giving his audience the opportunity to become haele by believing in the rood also".

Such an observation is actually an endorsement of the pattern of Christian heroism depicted in The Dream. Ordinary people may become heroes, in contrast to Germanic tradition, where only males who have proved themselves worthy through heroic deeds may be given the appellation. It is Christ who has made ordinary people worthy, so that by no power of themselves may they claim worthiness. Those who believe in the significance of the Crucifixion are saints primarily because of Christ. But further, the dreamer is only called hoele in certain contexts, when he is invoked and set apart from others. The poet has thus indicated that he is not like other people, but singular because ennobled by his vision. Even in Christian heroic tradition, therefore, some people are more holy than others, in so far as they are able to trust God more. The degree of sanctity is in direct proportion to the extent to which people rely on God, and inversely related to dependence on their own strength (cf. Hebrews 12:12). But all people who believe in the power of the Cross, says the poet, are heroes; and they are so because of the victory of Christ.

s See for instance Woolf (1958:150) who remarks that "by a tremendous and ironic reversal of the values of the heroic code, it has to acquiesce in and even assist in the death of its lord, forbidden either to protect him or avenge him". Also Greenfield (1965:138). 
Catherine Woeber

\subsection{Christ as poetic hero}

That Christ hastens to his death with all the resolution and boldness of a Germanic hero is a commonplace of criticism on the poem. In contrast to his depiction in other poems, like Christ III from the Exeter Book, or even to the Gospel accounts, as suffering the ignominy of being nailed to an instrument of torture, of undergoing all the pain and humiliation of mortality, he hastens with great zeal (efstan elne micle, 34a) and is determined to climb up on the Cross (he me wolde on gestigan, 34b). He is an active, even eager agent in the tradition of heroic valour:

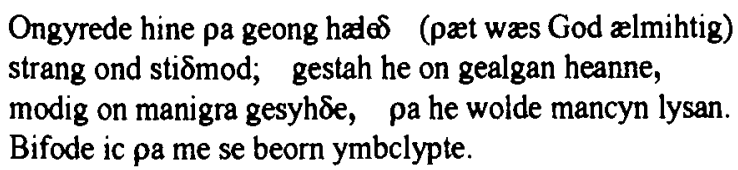

[Then the young hero (who was God Almighty), firm and unflinching, stripped himself. He leaped on to the high cross, brave in the sight of many, determined to free humankind. I trembled when the young man clasped me.]

We might note a few points here. First, Christ strips himself, and does not undergo the humiliation of being stripped by mocking soldiers. Woolf (1958:147) has pointed out an interesting parallel in The Aeneid (V:241ff) where Entellus strips himself for a heroic encounter, an example of a voluntary and heroic act. But the early Church Father Ambrose made the observation that, just as Adam in his defeat assumed clothing, so Christ in his victory laid them down (see Woolf, 1958:146). Second, Christ advances to do battle as a warrior might, mounting his horse and gripping his sword. Words such as gestah (leaped) and ymbclypt (clasped) are used purposely. Michael Cherniss has devoted an article (1972) to the depiction of the Cross as the sword of the warrior, showing how closely both inanimate objects which face the enemies of their lord are united in the poet's mind. It would have seemed natural to the poet, he argues, given the formulation of Christ as heroic warrior, to envisage the close relationship between Christ and the Cross as the same as the bond between a hero and his weapon, especially since the Cross assists in the ultimate defeat of his enemies. The word gestah (leap) is also used by Cynewulf in Christ II to describe Christ's Ascension; noteworthy are its connotations of glory and triumph. The word is appropriate here because of the victorious nature of Christ's sacrifice. Christ's voluntary action over- 
comes his opponent, Satan, and reverses the consequences of the Fall. This is the rationale for Christ's depiction as conquering hero in the mould of a Roman soldier in the mosaics at Ravenna, and as king reigning from the cross in Latin hymns by Fortunatus. The skill of this poet, then, consists in his weaving both heroic and Christian elements in his portrayal of Christ the victor on the Cross.

\subsection{The Cross as ethical hero}

But his creation is all the richer for his depiction of the Cross as victim. It is the Cross in The Dream who is the exemplar of the 'better' Christian heroism or, as Milton defines it, "patience as the truest fortitude" (Samson Agonistes 654). The Cross takes on the aspects of Christ's sufferings as a human being, leaving him free to be represented as the divine conqueror. Christian heroism, then, as conceived of in the poem, is that of fallen humanity, made worthy through Christ's triumph, and determined to strive for perfection (cf. Matthew 5:48). It is markedly different from Germanic heroism, represented by Beowulf, who is seen as the almost godlike hero, intent on maintaining his own reputation and protecting his people. The Cross represents the suffering of Christ as human:

purhdrifan hi me mid deorcan næglum; on me syndon pa dolg gesiene, opene inwid-hlemmas. Ne dorste ic hira nænigum sce $\delta$ an.

Bysmeredon hie unc butu ætgædere. Eall ic wæs mid blode bestemed, begoten of $\rho æ s$ guman sidan, si $\delta$ an he hæfde his gast onsended.

Feala ic on pam beorge gebidan hæbbe wraora wyrda.

[They pierced me with dark nails; the malicious wounds are still to be seen on me. I did not dare to hurt any of them. They insulted us both together. I

6 An overview of the scholarship on the relationship of Old English poetry to its Latin sources is well discussed by Alexandra Hennessey Olsen (1984). The relationship is a vexed one, primarily because the critic can never be sure what, in fact, the poet read since only three poets appended their signature to their poems, namely Caedmon, Bede and Cynewulf. For a discussion of the sixth-century poet Venantius Fortunatus' influence on Alcuin of York see Christine Fell (1991:177178) where she remarks how "Venantius, a Christian, was as happy to chant Virgil to himself for recreation as the psalms ... The Anglo-Saxons similarly had a poetic and cultural inheritance which did not disappear because of Christian-educated literary sensibilities". 
was all covered with blood, shed from the man's side when he had sent forth his spirit. I underwent many cruel things on that hill.]

The Cross by its passive endurance becomes a surrogate for Christ. It undergoes the humiliation and suffering which are the marks of a Christian hero - and more, in obedience to the plan of divine salvation, it

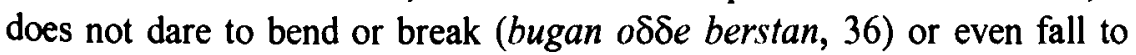
the ground (feallan to foldan sceatum, 43). It wants to protect Christ from his enemies, but it stands firm at his command. Patience and obedience under such duress make the Cross exemplary within Christian tradition.

By identifying the Cross with Christ, the poet has linked the idea of sacrificial offering and divine victory. The Cross is inanimate weapon, heroic retainer - and representative of Christ's humanity. Christ is Germanic warrior lord - and victorious Christian king. In the unification of the two figures by the death on the Cross, we observe the highest example of Christian valour: victory brought about by obedience and suffering. This is clearly conveyed through the skilful use made of heroic convention. Not only is the chief figure in the poem, Christ, a warrior engaging in a conflict (gewinne, 65), but the apostles and other followers are depicted - like one aspect of the Cross - as his retainers. Christ is not a warrior lord in name only; his comitatus surrounds him. The apostles are described by the heavily Germanic word hilderincas (warriors, 61b) and the friends who discover the Cross are called thanes of the lord (75b). Furthermore, the actions of these retainers are integral to heroic tradition. The Cross's bowing down to deliver its holy burden to the apostles (hnag ic hwasore pam secgum to handa/easmod elne mycle, 59-60) and the apostles' singing a dirge as they prepare the sepulchre for their lord (Ongunnon him $\rho a$ sorhleod galan/earme on $\rho a$ afentide, 67-68) are examples of the duty of a retainer in service to his lord, echoing the ritual lamentation at the grave of Beowulf (3148ff) mentioned above. This heroic imagery is successful because the metaphors are lightly drawn to suggest the aura of Germanic tradition, which enriches the Gospel account, without detracting from its truth or significance. 


\section{Christ II and Christ and Satan}

We move on now from the active Germanic heroism of Christ in The Dream of the Rood to his active Christian heroism in Cynewulf's Christ II and the anonymous Christ and Satan. It should be stressed that the difference between the two is in the heroic act itself. In The Dream Christ's feat of redemption on the cross is essentially passive; in death he conquers. Hence the description of him as a warrior in the Germanic mould is metaphorical (an example of the miles Christi metaphor). ${ }^{7}$ But in the other two poems his actions are indeed active: he literally fights for his Father in the Expulsion of Satan, and in the Harrowing of Hell. He is not only like a warrior; he is one, in the Christian sense. Christ the warrior manifests Christian heroism in his overcoming Satan in the iustum bellum of the spiritual realm. ${ }^{8}$ In The Dream the poet's ingenuity lay in his portrayal of the passive act as an active achievement, and the resultant blending was very successful. The poets of Christ II and Christ and Satan had the easier task of describing Christ's warlike feats in the appropriate diction of Germanic heroic decds. The synthesis was no less effective. When heroic elements appear, they have been adapted to the expression of Christian ideas. The poets are not, by and large, concerned with confronting Germanic heroism with the Christian ideal but they employ the Germanic ideal of pride to account for the disloyalty of Satan to his leader, God. In Christian terms the Devil is the rebel and outcast; in the Germanic view he is the faithless retainer and eternal exile. His heroic fortitude, though laudable for its courage in Germanic terms, is nevertheless a specious heroism in the Christian view because it is in direct conflict with the will of God.

7 That this image of the miles Christi is a topos in its own right is shown by the story of Martin of Tours who refused to fight for the Emperor Julian with the bold words "Christi miles sum; pugnare mihi non licet". He paradoxically assumes the role of soldier and withdraws from combat. For further discussion of this metaphor see Janet Hill (1981).

8 Milton (1878: 479) describes the iustum bellum as "the deeds and triumphs of just and pious nations doing valiantly through faith against the enemies of Christ". The Archangel Michael's casting out of Satan from heaven (Revelation 12) and Christ's final victory over Satan (Revelation 19) are examples of this concept in the heavenly realm. 


\subsection{The descent-ascent motif}

The protagonist Christ, however, in both poems brings his will in line with that of his Father, both in his active deeds as deity in the Expulsion of Satan and the Harrowing of Hell, and in his passive endurance as man in the Temptation and the Crucifixion. Significant actions in both poems will be compared for an important reason: the descent-ascent motif (as termed by Brown, 1974) or humiliation-exaltation theme (Sleeth, 1982) is common and integral to both. In Christ II Cynewulf focuses on the Ascension, the glorification of Christ after his self-abasement in the Incarnation: Christ ascends because he voluntarily descended. Likewise the Harrowing of Hell could only occur after his Passion on the cross: he descends to victory after being raised up in death. It is only suffering and humiliation willingly undergone which brings triumph; this is Christian heroism. The tripartite structure of Christ and Satan underlines the same theme: the first section presents Satan who, exalting himself in heaven, is humbled and thrust down to hell; the second, Christ who, because he suffered for humanity on the cross, gained the victory in harrowing hell; and the third focuses on the showdown between the two antagonists, in which patient endurance vanquishes presumption. In active and passive deeds, Christ is hero.

Each of the primarily passive acts of Christ in lines 720-755 of Christ II is, interestingly, called a 'leap' ( $h l y p$ ), essentially an active endeavour. Cynewulf must have been aware of the victory inherent in the humiliation and endurance of Christ, as were his probable prose sources. ${ }^{9}$ The first four 'leaps' are passive: Christ is conceived, taking on human flesh and emptying himself of glory (cf. Philippians 2:6-11). Second, he is born as a humble infant, later is put to death on the cross, and is then laid in the tomb. In willingly undergoing our human lot, he gains the triumph of vanquishing his foes. He then releases the righteous souls from the clutches of hell, and ascends in glory to his Father. These last two 'leaps'

9

Cook (1964:144) suggests that these include Ambrose and Alcuin, who comments on Song of Songs $2: 8$ ("Saliens super montes, et transiliens super colles") thus: "Tales enim saltus fecit dilectus meus; de caelo venit in uterum, de utero in praesepe, de praesepe in crucem, de cruce in sepulchrum, de sepulchro rediit in caelum".

Koers 60(3) 1995:359-379 
Heroism in three Old English poems: A Christian approach

are obviously active. It is interesting that, in this poem, Christians are exhorted to believe in the truth of the Ascension for their salvation, whereas more conventionally in The Dream it was incumbent on them to have faith in the significance of the Crucifixion. But both events are crucial in that they exemplify Christ exalted; yet one is active and the other passive.

This descent-ascent motif is clearly brought out in the passage under discussion. Cynewulf uses the parallel construction "it was the first (second) leap when ..." to play one 'leap' off against the other. So pa he on fiemnan astag (when he descended into the womb, 720 ) is countered by $\rho a$ he on rode astag (when he rose on the cross, 727); $\rho$ a he pone beam ofgeaf (when he forsook the tree, 729) finds its opposite in $\rho a$ he to heafonum astag (when he rose to heaven, 737). The other two 'leaps', those of the Incarnation and Harrowing of Hell, though both descents, are similarly contrasted: the baby $\rho a$ he in binne was (when he was in the manger, 724) with the conqueror pa he hellwarena heap forbygde (when he hurled down the host of hell, 731). It is Satan who then becomes the one who lies in the dungeon shackled with sins (clommum gefoestnad, 735), just as the infant was once swaddled in garments (clapum bewunden, 725). This alternation in the status of Christ and his adversary Satan will be examined more fully in the discussion of Christ and Satan. Cynewulf closes the passage with an exhortation to Christ's comitatus on earth, the gepungen pegnweorud (751), to follow Christ's footsteps, as it were, in ascending to heaven. Christian heroism, then, is not the exclusive preserve of doughty and exalted warriors, but the call of all believers, through the merits and grace of Christ. Yet the most patient and humble of these 'thanes' deserve the appellation more than others, for they reflect most clearly the virtues of their leader, who conquered when he suffered most.

This paradox is the pivot on which the poet of Christ and Satan has centred his poem. Barbara Raw (1991:231-232) has suggested that this poem complements the Junius MS's Genesis $A$ and $B$ by showing Christ's reversal of humanity's Fall. Genesis $B$ had described the origin of Satan's feud with God and his success in seducing Adam and Eve from their allegiance to God. Christ and Satan presents a series of Christ's conflicts with Satan which culminate in the release of Adam and Eve from hell and their reinstatement as God's servants. The figures of Christ and Satan are 
Catherine Woeber

integral to the working out of the abasement-exaltation motif in each of the three parts of the poem. They are only indirectly played off against each other in the first two parts, yet the contrast is exceptionally clear in the opening lines of the poem. The picture of Christ the creative Word, exalted but humbling his Godhead in the act of creation, has a foil in the subsequent portrayal of Satan, in perdition for striving to raise himself above the Godhead. Close scrutiny of the parallelism of two passages in this poem, as suggested by Sleeth (1982), will highlight the contrast in the poet's mind of self-exaltation which abases, and self-denigration which glorifies.

Hwearf $\rho$ a to helle $\rho$ a he gehened wæs,

Godes andsaca; dydon his gingran swa

gifre and grædige, $\rho$ a he God bedraf

in pæt hate hof pam is hel nama.

[Then God's foe passed to hell when he had been vanquished. His followers did likewise, insatiate and greedy, when God drove them into that hot place whose name is hell.]

Hwearf $\rho$ a to helle hæle $\delta$ a bearnum

Meotud purh mihte; wolde manna rim

fela pusenda for $\delta$ gelædan

up to esle.

(400-403a)

[Then God through his might passed to hell, for the sake of the children of men. He was determined to lead forth myriads of people up to his home.]

Both the humbled Satan and powerful Christ descend to hell; Satan because he is the adversary of God, and Christ because of his compassion for humanity. So Satan is shown as going to hell involuntarily in the abasement which follows his aspiration, and Christ as descending by his own decision, in the last and lowest of his 'leaps' that leads to his supreme exaltation. Satan's followers as well are involuntarily humbled by their cupidity; Christ as active hero drives them down to hell. The thanes of Christ, on the other hand, are raised up to heaven. It should be noted that the comitatus of Satan is the subject of an active verb dvdon, but that of Christ the object of geloedan: its role is entirely passive. This is in keeping with Christian heroism, waiting upon God; ${ }^{0}$ and also suggests

10 The idea of waiting upon God finds its most moving expression in Milton's bestknown sonnet, no. 19, on his blindness at the age of forty-three. He struggles with

Koers 60(3) 1995:359-379 
Heroisn in three Old English poems: A Christian approach

that they are exalted as heroes not on their own merits alone, but through the victory-sacrifice of Christ. This, the Crucifixion, is recognised by the poet as a glorious deed (fager waes pat ongin) in lines 547-557, heroic in itself because Christ voluntarily mounted the cross, and also in its consequences, since in his death he overcame Satan. Christ denigrated himself in order that his followers be raised up in heaven. Satan tried to exalt himself, with the result that his thanes were abased in hell. The abasement-exaltation theme is reinforced in both poems by the description of the last and lowest descent, the Harrowing of Hell.

\subsection{The Harrowing of Hell}

Both Cynewulf in Christ II and the poet of Christ and Satan present Christ as the active Christian warrior fighting and vanquishing his adversary in order to lead the righteous souls to his Father. Cynewulf, however, includes many more heroic details, so that the triumph becomes like that of a Germanic warrior returning from a successful military exploit. The song of welcome by the angels in lines 558-585 is couched in Germanic heroic diction: Christ has plundered hell (helle bireafod, 558) of its tribute (gafoles, 559) so that the Devil's warriors (deofla cempan, 563) are deprived of prosperity (duguסum bidceled, 563):

Ne meahtan wiperbreocan wige spowan

wæpna wyrpum, sippan wuldres Cyning,

heofonrices Helm, hilde gefremede

wip his ealdfeondum Anes meahtum;

pær he of hæfte ahlod hupe mæste

of feonda byrig folces unrim

(564-569)

[His adversaries could not succeed in battle by casting weapons after the King of Glory, the Protector of the Kingdom of Heaven, made war through the might of One against his ancient foes. There he delivered from bondage the greatest of spoils, a vast host of people from the fortress of his enemies.]

his despair over the fact that his blindness prevents him from actively serving God. Fully cognisant as we have seen of the kind of Christian heroism exemplified in the Suffering Servant and Job, Milton finds solace in the last six lines which show the alternative way of service through submission and contemplation: "They also serve who only stand and wait". For more discussion of this poem, see Ryken (1979:50-52). 
After the 'battle play' ( $g u \delta p l e g a n, 573$ ) he returns to his city to resume his throne (giefstol, 572). He gives treasure and rewards to his followers (giefe sealde, 660) in the manner of a Germanic king. Such diction, however, is obviously metaphorical. Cynewulf does not conceive of Christ as the Germanic warrior, but uses heroic terminology to enrich the description of his active harrowing and subsequent glory. The metaphor is quite apposite, for Christ is the Christian warrior, and his victory is a literal one; even the giving of gifts has Scriptural sanction (cf. Ephesians 4:8). Moreover, Cynewulf has precedent in treating Christ's return thus: the questions and answers of Psalm 24:7-10 were connected by the Church Father Origen with the Ascension of the victorious Christ." Brown (1974:9) mentions that Gregory of Nyssa coupled Christ's descent into hell and his Ascension because of the repetition of the question in the psalm "Who is the King of Glory?" He made the angels first challenge Christ as he descends to do battle, and then again on his return as he ascends to heaven. Cynewulf does the same, recalling the Harrowing of Hell with wuldres Cyning (King of Glory, 565) and Christ's Ascension in geatu ontyna6! (Open up the gates! - 576).

The poet of Christ and Satan, however, handles the Harrowing of Hell more imaginatively. He describes the victory itself, ingeniously using the reactions of captors and captives alike. Christ is the soldier with his legions (pegen mid preate, 388) and the prince of angels (peoden engla, 388) but his portrayal as conqueror depends for its effectiveness on the lamentations of the devils:

Nu $\delta$ es egsa com,

dyne for Dryhtne, sceal pes dreorga heap

ungeara nu atol prowian.

Hit is se seolfa Sunu Waldendes,

11 "When he comes, conquering and triumphant, with his body which has risen from the dead, then certain of the Powers say, "Who is this that comes from Edom, with reddened garments from Bozrah, in such splendour?' Then those who escort him say to those who are set in charge of the heavenly gates, 'Open your gates, you rulers, open your everlasting portals, and the King of Glory shall come in'. But they inquire yet again, if one may so describe it, seeing his right hand red with blood, and his whole body covered with the marks of his valour" (In Brown, 1974:9).

Koers 60(3) 1995:359-379 
Heroism in three Old English poems: A Christian approach

engla Dryhten. Wile uppe heonan

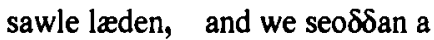

$\rho æ s$ hereweorces hen $\delta$ ge

(393b-399)

[Now that this dread might has come, the loud noise of the Lord, this sorrowful host will straightway suffer anguish. It is the Son of God himself, the Lord of angels. He will take the souls up from here, and we shall then forever endure humiliation because of his wrath.]

It is the terror of the fiends which makes Christ's action all the more striking. He has vanquished them (oferfohten, 405) in their age-old hostility (fceh $\delta, 405)$. Yet this victory is obliquely portrayed by their fear and abasement, rather than by emphasising Christ as soldier in the Germanic mould. Cynewulf uses heroic diction and thought to portray the triumph; the poet of Christ and Satan, in keeping with his abasementexaltation theme, stresses the one, say, the denigration of the devils, which necessarily evokes the idea of the other, the glorification of Christ in his victory. Cynewulf emphasises his motif through the literal descent and ascent of Christ as the King of Glory; the unknown poet evokes his in the depiction of the respective states of humiliation and victory. ${ }^{12}$ Yet in both poems Christ is the active warrior, winning the iustum bellum, like a Germanic warrior in his might, but indeed a Christian hero in his doing the will of his Father.

\section{Conclusion: The weltanschaulich framework}

Through discussion of the above three poems, we can see the effectiveness of the description of Christ as Christian hero in terms culled from Germanic tradition. Problems which certain critics find with the marriage of the two conventions generally arise because cognisance has not been taken of the force of Christian heroism.

If, however, awareness of the strength of the heroic battle tradition in Old English were matched by an equal awareness of the strength of the saint as miles Christi, the critic might recognise more easily that we do not always

12 It should be pointed out that, although the devils suffer and feel pain, theirs is a far cry from Christian patience in that it is involuntary. A Christian hero willingly endures; his/her will is aligned with the divine. The question of will is absolutely crucial to the issue of heroism: Christ and Christian saints are heroes in so far as their will is in line with God's (cf. Ephesians 5:15-17). 
Catherine Woeber

have in poetic hagiography a simple redeployment of traditional poetic diction, with its traditional heroic connotations, but an informed response to the Christian warrior metaphor in which the poet may be both explicit about his aims and selective in his use of battle vocabulary (Hill, 1981:51).

It is clear that the Anglo-Saxon poets do not wish their Germanic heroic terminology to be taken literally. "Recourse to the Germanic ethos, inherent to some extent in the alliterative poetic itself, could also function as a strategy aimed at transforming the urge to violence in literal machia into the psychomachia which the Christian is called upon to wage" (Hermann, 1982:31). Thus the aim of the three poets has been to employ heroic vocabulary so that not only will Christ be seen as a figurative warrior (the 'poetic' hero); but more, he will be seen literally as a warrior in his own right (the 'ethical' hero) to be emulated by readers of the poems.

What, then, has Ingeld to do with Christ? That heroic ideals gave way to Christian subject matter in Old English poetry is beyond question. If heroic vocabulary remained, it was due to more than the conservative force of such diction. This article has suggested that poets recognised the existence of a Christian heroism distinct from that of the older Germanic warriors and used the heroic diction in a new context. Ryken (1979:69) shows how Milton, similarly, centuries later was much influenced by the Roman elegiac poets, whose ethical viewpoint he gradually came to deplore, but whose art he still applauded. ${ }^{13}$ If some Old English poems are more successfully integrated than others, it is because of that poet's sensitivity to the concepts of Germanic and Christian heroism, and sometimes his skill in combining the vocabulary of one with the subject matter of the other. Those critics who find fault with the use of heroic diction to describe the heroic acts of Christ fall foul of the error of

13 Ryken (1979:69) gives Werner Jaeger's comment that "it was the Christians who finally taught men to appraise poetry by a pure aesthetic standard - a standard which enabled them to reject most of the moral and religious teaching of the classical poets as false and ungodly, while accepting the formal elements in their work as instructive and aesthetically delightful". Many Anglo-Saxon poets were unreserved in affirming, through their appropriation of its diction and metaphor, the value of Germanic poetry in its craftsmanship and beauty. "A Christian world view and a Christian aesthetic make the pursuit of beauty an obligation, not an option" (Ryken, 1979:36).

Koers 60(3) 1995:359-379 
Heroism in three Old English poems: A Christian approach

myopically translating and reducing the nature of Christian heroism into something they themselves can understand, and so remain blind to its true nature. They fail to implement T.S. Eliot's well-known exhortation, that "literary criticism should be completed by criticism from a definite ethical and theological standpoint" (1975:97), that Christian readers and critics have "a duty of maintaining consciously certain standards and criteria of criticism over and above those applied by the rest of the world" (105).

This article has shown that only Christian scholarship is able to make this poetry "intelligible, ready for reading, to expose its weltanschaulich framework and point out significant symbolical detail that will bring the reader to the work (again) with sharpened perception and a more fruitful, aesthetically trained interest" (Seerveld, 1968:103). The poet of The Dream of the Rood mingled heroic and Christian imagery in his representation of Christ and the Cross: Christ as Germanic warrior engaged in an essentially passive battle, and the Cross enduring his Passion as a loyal retainer. The mingling is also evident in Christ II, where Christ is portrayed as a victorious lord returning to his royal hall, yet only because he has plumbed the abasement which will lead to his exaltation. The poet of Christ and Satan took words expressive of heroic concepts, like a lord's generosity to his retainers, and used them to convey the essentially giving nature of the Godhead: Christ's free act of creation and his compassion in redeeming humanity as opposed to Satan's covetousness. Only a Christian literary criticism can show how the Anglo-Saxon poets, by enlisting heroic terminology which valorised battle in the service of the essentially passive struggle characterising Christian heroism, made use of the earlier tradition for gloriously different ends while working within the confines of poetic convention.

\section{Bibliography}

BROWN, G.H. 1974. The Descent-Ascent Motif in Christ II. Journal of English and Germanic Philology, 73:1-12.

CALDER, D.G. 1981. Cynewulf. Boston : Twayne.

CHERNISS, M.D. 1972. The Cross as Christ's Weapon. Anglo Saxon England, 1:240-252.

COOK, A., ed. 1964. The Christ of Cynewulf. Connecticut : Archon Books.

DUBS, K.E. 1975. Hæle8: Heroism in The Dream of the Rood. Neophilologus, 59:614-615. 
ELIOT, T.S. 1975. Religion and Literature. (In Kermode, F. ed. Selected Prose of T.S. Eliot. London : Faber. p. 97-106.)

ETCHELLS, R. 1972. Unafraid to Be: A Christian Study of Contemporary English Writing. Downers Grove, IL : InterVarsity Press.

FELL, C. 1991. Perceptions of Transience. (In Godden, M. \& Lapidge, M., ed. The Cambridge Companion to Old English Literature. Cambridge : University Press. p. 172-189.)

GREENFIELD, S.B. 1965. A Critical History of Old English Literature. London : University Press.

HERMANN, J.P. 1982. The Recurrent Motifs of Spiritual Warfare in Old English Poetry. Annuale Mediaevale, 22:7-35.

HILL, J. 1981. The Soldier of Christ in Old English Prose and Poetry. Leeds Studies in English, 12:57-80.

KRATZ, D.M. 1980. Mocking Epic: Waltharius, Alexandreis and the Problem of Christian Heroism. Madrid : Jose Porrua Turanzas.

MILTON, J. 1878. The Reason of Church Government. (In St John, J.A., ed. The Prose Works of John Milton. London : Bell \& Sons.)

MILTON, J. 1973. De Doctrina. (In Kelley, M., ed. The Collected Prose Works of John Milton. New Haven : Yale Press.)

O'BRIEN O'KEEFFE, K. 1991. Heroic Values and Christian Ethics. (In Godden, M. \& Lapidge, M., ed. The Cambridge Companion to Old English Literature. Cambridge : University Press. p. 107-125.)

OLSEN, A.H. 1984. Speech, Song and Poetic Craft: The Artistry of the Cynewulf Canon. New York : Peter Lang.

RAW, B.C. 1991. Biblical Literature: The New Testament. (In Godden, M. \& Lapidge, M., ed. The Cambridge Companion to Old English Literature. Cambridge : University Press. p. 227-242.)

RYKEN, L. 1979. Triumphs of the Imagination: Literature in Christian Perspective. Downers Grove, IL : InterVarsity Press.

SEERVELD, C. 1968. A Christian Critique of Art and Literature. Toronto : Association for Reformed Scientific Studies.

SHIPPEY, T.A. 1972. Old English Verse. London : Hutchison.

SLEETH, C.R. 1982. Studies in Christ and Satan. Toronto : University Press.

STEADMAN J. 1969. Milton and the Renaissance Hero. Oxford : Clarendon Press.

WOOLF, R. 1958. Doctrinal Influences on The Dream of the Rood. Medium Aevum, 27:137-153.

WOOLF, R. 1968. The Devil in Old English Poetry. (In Bessinger, J. \& Kahrl, S., ed. Essential Articles for the Study of Old English Poetry. Connecticut : Archon Books. p. 164-179.) 
